Teologia i Moralność, volumen 16(2021), numer 1(29)

doi: 10.14746/TIM.2021.29.1.8

ORCID: 0000-0002-5742-9428

JACEK BRAMORSKI

Akademia Muzyczna im. Stanisława Moniuszki w Gdańsku

\title{
Filozoficzno-teologiczne źródła muzykoterapii w starożytności i średniowieczu
}

Przekonanie o terapeutycznym oddziaływaniu muzyki towarzyszy ludzkości od najdawniejszych czasów. Świadectwem tego są wydarzenia opisane w Biblii, pisma antycznych myślicieli, jak również prehistoryczne rysunki odnajdywane $\mathrm{w}$ jaskiniach oraz starożytne zabytki malarstwa. O najwcześniejszych medycznych zastosowaniach muzyki możemy także wnioskować na podstawie obserwacji zwyczajów plemion ludzi pierwotnych, żyjących jeszcze do dziś, którzy rytualnym tańcem, rytmem i śpiewem leczą członków swojego plemienia. Obecnie muzykoterapia uznana jest za jedną z metod wspomagających kompleksowe oddziaływanie lecznicze, m.in. w psychiatrii, neurologii, kardiologii, dermatologii, geriatrii, stomatologii i opiece paliatywnej.

Terapeutyczny wpływ muzyki jest przedmiotem wieloaspektowych badań naukowych, zwłaszcza w zakresie medycyny, psychologii i pedagogiki. Należy jednak pamiętać, że muzykoterapia jako nauka interdyscyplinarna, korzystająca z osiągnięć medycyny i muzykologii, powinna być rozpatrywana w szerokim kontekście humanistycznym, w którym obecna jest refleksja filozoficzno-teologiczna. Niestety, wymiar ten nie jest w wystarczającym stopniu uwzględniany w analizach muzykoterapeutycznych. A przecież od czasów antycznych bliski związek sztuki, a zwłaszcza muzyki z medycyną, ma źródło w tych dwóch dziedzinach, czyli w szeroko pojętej perspektywie etyczno-antropologicznej. Pacjent to osoba ludzka, czyli jedność psychofizyczna, której istotę oddaje łacińskie określenie corpore ed anima unus (,jeden ciałem i duszą"). Katechizm Kościoła katolickiego przypomina, że jedność ciała i duszy jest tak głęboka, że można uważać duszę za „formę” ciała. Dzięki duszy ciało 
utworzone z materii jest ciałem żywym i ludzkim; duch i materia w człowieku nie są dwiema połączonymi naturami, ale ich zjednoczenie tworzy jedną naturę (por. Katechizm Kościoła katolickiego, 365; Góźdź 2010, 53-58).

Ten antropologiczny fundament jest niezwykle ważny nie tylko w personalistycznym podejściu do pacjenta, ale także w zrozumieniu ścisłej relacji pomiędzy elementem duchowym i materialnym człowieka. Zwraca na to uwagę słynna maksyma Hipokratesa: „By leczyć ciało ludzkie, konieczna jest wiedza o całości zjawisk”. Uchwycenie tej „,całości”, czyli głębokiej jedności psychofizycznej w perspektywie filozoficzno-teologicznej, jawi się jako istotny problem badawczy we współczesnym dyskursie naukowym w zakresie muzykoterapii. Potrzebne jest dowartościowanie w analizach terapeutycznego oddziaływania muzyki powszechnego i niezbywalnego elementu kondycji ludzkiej, jakim jest otwartość i ukierunkowanie na Boga. Człowiek jako homo religiosus i capax Dei, doświadczając swej niewystarczalności i kruchości, dąży do przekroczenia tych ograniczeń i odnalezienia wartości, które nadadzą sens jego egzystencji (por. Klimowski 2015, 99-102). Otwartość na Byt Transcendentny leży zatem u źródeł integralnie rozumianej muzykoterapii, o czym świadczy tradycja myśli antycznej i biblijnej oraz koncepcje średniowieczne.

\section{Leczniczy charakter muzyki w tradycji antycznej}

W starożytnych Chinach i Indiach powszechnie zajmowano się leczniczym oraz etycznym charakterem muzyki, czego wyrazem są traktaty opisujące skale muzyczne, konstrukcje melodyczne oraz rytmy mające zdolność oddziaływania na stan zdrowia człowieka. Do najważniejszych świadectw dalekowschodniego kręgu kulturowego należy w tym zakresie Księga obyczajów - Liji (V w. przed Ch.). Według niej muzyka oddziałuje na wnętrze, obyczaj zaś wpływa na postawę zewnętrzną człowieka. Dlatego należy starać się, aby działanie obyczaju ograniczyć, wpływ muzyki zaś potęgować. Jeden z najstarszych tekstów medycznych (ok. 1550 r. przed Ch.) umieszczony na tzw. $P a$ pirusie Ebersa, zawiera wiele śpiewanych wskazówek dla lekarzy starożytnego Egiptu. Stosowali je oni jako inkantacje w celu uzdrowienia chorych (por. Thaut 2015, 143-158; Y. Wu 2019, 84-92; David 2008, 181-194; Szwed 2005, 177-178).

Pierwsze sklasyfikowanie oraz systematyczne wykorzystanie w praktyce terapeutycznej określonych rodzajów muzyki zawdzięczamy starożytnym Grekom. Już u początków sztuki helleńskiej odnaleźć można przekonanie o uzdrawiającej mocy chorei, łączącej w sobie muzykę, taniec i poezję. Na jej wspólne pochodzenie z medycyną wskazywał w traktacie $O$ muzyce Pseudo-Plutarch (por. Pseudo-Plutarch 1992, 24; Szczeklik 2003, 80-81). Przedsta- 
wiciele szkoły pitagorejskiej przyjmowali jako podstawowe kryterium oceny muzyki stosunki liczbowe, a także interwały i rytmy (por. West 2003, 261). Taka zasada stała się źródłem jednej z najważniejszych koncepcji, dotyczącej terapeutycznego znaczenia muzyki jako katharsis, czyli oczyszczenia - to pojęcie wielokrotnie powraca w tekstach pitagorejczyków (por. Podbielski 2004, 546).

Charakterystyczną cechą antycznego pojmowania muzyki było uznawanie siły jej oddziaływania na usposobienie słuchaczy. Uważano, że może ona człowieka uspokajać, pocieszać, odrywać od codziennych trosk, a także pobudzać i wprowadzać w stan uniesienia, a nawet szału. Dlatego Grecy rozmyślnie posługiwali się muzyką w celu oddziaływania na nastroje ludzi. Przykładem tego jest uspokojenie wzburzonego thumu śpiewem Terpandra podczas zamieszek, które w połowie VII wieku przed Chr. wybuchły w Sparcie (por. West 2003, 45). Muzyka obecna była w codziennym życiu Greków, nie tylko towarzysząc rytuałom religijnym czy uroczystościom, ale nade wszystko przenikając proces wychowania i duchowego dojrzewania człowieka, prowadząc go ku kontemplacji piękna. Ten szczególny wymiar helleńskiego rozumienia i doświadczania muzyki nosi nazwę „etosu muzycznego” (por. Cates 2013, 31-41; Bramorski 1998, 21-82; Mathiesen 1984, 264-279).

Zasługą pitagorejczyków było nadanie filozoficznych podstaw, sięgającemu czasów prehistorycznych - przeświadczeniu o terapeutycznej mocy muzyki. Sformułowali oni katartyczną koncepcję muzyki jako oczyszczającego lekarstwa dla ludzkiej duszy, nadając jej funkcję etyczną i wychowawczą (por. West 2016, 51-68; Fubini 1997, 35). Pitagoras i jego uczniowie nie tylko sklasyfikowali, ale także stosowali w praktyce typy muzyki wywołujące różnorodne skutki, zarówno pobudzające, jak i uspokajające. W codziennym życiu sami wykorzystywali uzdrawiające oddziaływanie muzyki, gdy udając się na spoczynek, oczyszczali umysły z niepokoju i zgiełku dnia poprzez specjalnie dobrane melodie, dzięki którym odzyskiwali spokój. Rankiem, po przebudzeniu, aby dobrze rozpocząć dzień, śpiewali pieśni, które pomagały im uwolnić się od sennej ociężałości i podjąć obowiązki. Wśród pitagorejczyków panowało przeświadczenie, że muzyka wspomaga leczenie chorób ciała poprzez stosowanie inkantacji (zaklęć) i pieśni oczyszczających umysł. Pitagoras w terapii chorych posługiwał się zarówno wokalnymi inkantacjami, jak i muzyką instrumentalną. Tradycja pitagorejska podaje, że miał on śpiewać przy akompaniamencie liry peany Taletasa, aby wprowadzać swych uczniów w pogodny stan ducha, oraz uzdrawiające pieśni, lecząc choroby cielesne. Owocność tej muzykoterapii zależała od dobrania odpowiednich tonacji, skal i rytmów melodii granych na lirze bez słów. W okresie hellenistycznym późniejsi pitagorejczycy podejmowali nawet próby wykorzystania magicznego brzmienia liry, aby wyzwalać dusze z więzów śmierci. Świadczy o tym słynny mit o Or- 
feuszu, który grając na lirze, pokonał groźne siły Hadesu i wyprowadził swoją ukochaną żonę Eurydykę z krainy umarłych. Ta mitologiczna scena stała się archetypem mocy muzyki i miłości, inspirując zarówno do poszukiwań naukowych, jak i artystycznych (por. McClary 2007, 155-159; Gioia 2006, 69-88; West 2003; James 1996, 38).

Znalazło to wyraz w poprzedzających erę homerycką wierzeniach orfickich, których istotnym elementem było doświadczenie uzdrawiającego oddziaływania muzyki. Według nich dusza uwięziona w ciele dostępowała wyzwolenia poprzez oczyszczenie, do którego prowadziły misteria orfickie, związane z tańcem, śpiewem i grą na instrumentach (por. Rybowska 2020, 23-51; Zarewicz 2009, 225-240; Eliade 1988, 256-259). Przedstawiciele szkoły pitagorejskiej nie poprzestawali w swoich filozoficznych dociekaniach na dążeniu do poznania porządku kosmicznego, ale zajmowali się także refleksją etyczną i teologiczną. Uważali, że odkrycie praw harmonii warunkujących strukturę wszechświata oraz ludzkiej psyche umożliwia zbliżenie się do sfery sacrum, stanowiąc podstawę moralności. Poznanie poprzez muzykę istoty kosmicznego porządku umożliwiało człowiekowi bezpośredni kontakt z boskością (por. Dembiński 2010, 51-52; Huffman 2009, 21-44; Gajda 1996, 163).

Według pitagorejczyków muzyka miała głęboki sens religijno-etyczny, gdyż wyzwalała i oczyszczała ludzką duszę. Dzięki temu zajmowała pośród różnych dziedzin sztuki miejsce szczególne, stając się darem bogów. Nie była tylko dziełem człowieka, ale objawiała nadrzędne zasady, boski wzorzec, do którego winien się on stosować. Co więcej, muzyka, będąc głosem duszy, wyrażała to, co w ludziach najgłębsze i najpiękniejsze. Człowiek wypowiadał się poprzez śpiew, grę na instrumencie oraz rytmy, ukazując to, co w nim najbardziej wewnętrzne - swoją psychikę i charakter (por. Provenza 2014, 300-314; Tatarkiewicz 2009, 97-98).

Do idei pitagorejskich nawiązał Platon, który uważał, że harmonia muzyki odzwierciedla harmonię duszy i harmonię kosmosu. Dzięki temu muzyka stanowi doskonałe narzędzie psychoterapeutyczne, wprowadzając harmonię do zachwianej równowagi duszy. Poszczególnym skalom muzycznym Platon nadawał wartości etyczne, uważając niektóre z nich za pożyteczne, inne zaś za szkodliwe dla wewnętrznej równowagi człowieka. W dziele pt. Państwo zawarł swoją interpretację skal muzycznych, uznając za dopuszczalne tylko te, które wyrażają ethos człowieka mężnego i opanowanego. Platońska koncepcja etosu muzycznego stworzyła podstawę dla greckiej paidei oraz praktyki muzykoterapeutycznej (por. Platon 2001, 94-101; West 2016, 57-65; Thaut 2015, 149-150; Jaeger 2001, 797-799).

Teorie Pitagorasa i Platona dotyczące terapeutycznego znaczenia muzyki zostały usystematyzowane w dziełach jednego z najwybitniejszych myślicieli antycznych - Arystotelesa. Według niego muzyka odgrywa rolę lekarstwa dla 
duszy, gdyż naśladuje uczucia, które niepokoją człowieka i z których pragnie się on oczyścić. Arystoteles w Polityce twierdził, że takie uczucia, jak „litość, strach, a także zachwyt”, dotyczą wszystkich ludzi, chociaż doświadczane są przez nich z różnym natężeniem - u jednych ,z wielką przejawiają się siłą”, a u innych z mniejszą. Ci bowiem, którzy są czymś silnie wstrząśnięci, słuchając ,świętych pieśni [...] wprawiających duszę w stan zachwytu, uspokajają się, jakby zażyli jakiegoś lekarstwa i środka uśmierzającego. Takie samo wrażenie muszą odczuwać ci, którzy są skłonni do uczucia litości i strachu, i w ogóle ludzie wrażliwi, inni zaś, o ile kogoś któreś z tych uczuć poruszy; wszyscy jednak odczuwają w takim razie pewne oczyszczenie i ulgę połączoną z rozkoszą. Podobnie i śpiewy o takim oczyszczającym dusze charakterze sprawiają ludziom nieszkodliwą uciechę" (Arystoteles 2001a, 224; por. Halliwell 2003, 499-517). Według Władysława Tatarkiewicza Arystotelesowska koncepcja muzycznego katharsis polegała nie tyle na „oczyszczeniu” uczuć poprzez ich uszlachetnienie, ile raczej na „oczyszczeniu” umysłu z uczuć poprzez ich wyładowanie. Dzięki temu słuchacz uwalniał się od „nadmiaru niepokojących go uczuć i zdobywał spokój wewnętrzny" (Tatarkiewicz 2009, 172). Katharsis miała również cel etyczno-wychowawczy, oczyszczając człowieka $\mathrm{z}$ wad, stając się swoistą metanoia, czyli nawróceniem (por. Krasnodębski 2009, 25).

Nawiązując do wcześniejszych osiągnięć pitagorejsko-orfickich, Stagiryta twierdził, że katharsis dokonuje się przez mimesis muzyczną. „Naśladownictwo" (gr. mimesis, łac. imitatio) stanowi jedno z kluczowych pojęć antycznej teorii sztuki. Prawdopodobnie jego pierwotne, etymologiczne znaczenie wywodziło się od „mima”, który w rytualnej chorei, poprzez śpiew i taniec, wyrażał przeżycia bohatera kultowego dramatu dionizyjskiego. W dziele zatytułowanym Poetyka Arystoteles wyjaśnia fundamentalne dla swej teorii sztuki pojęcie mimesis, pojmowanego jako akt twórczej kreacji (por. Arystoteles 2001b, 564-626). W koncepcji Arystotelesowskiej muzyka stanowiła jedną z najbardziej mimetycznych dziedzin sztuki, gdyż w rytmach i w melodiach odnaleźć można realistyczne naśladowanie ludzkich emocji i postaw. Autor Polityki zauważył: „Jest wielkie podobieństwo co do prawdziwej natury między rytmami i melodiami a gniewem i łagodnością, męstwem i rozwagą, i ich wszystkimi przeciwieństwami oraz innymi uczuciami etycznymi. Dowodzą tego fakty: słuchamy takich melodii i nastrój duszy naszej ulega zmianie. Od przyzwyczajenia się do tego, by smucić się czy cieszyć na widok podobieństw, blisko jest jednak do takiego zachowania się wobec rzeczywistości" (Arystoteles 2001a). Mimetyczna katharsis obejmuje całego człowieka, zarówno jego sferę uczuciową, jak i duchowo-moralną (por. Belfiore 1992, 345-347).

Dla Arystotelesa muzyczna katharsis pełniła funkcję terapeutyczną. Zwracając uwagę na zróżnicowany pod względem etycznym charakter poszcze- 
gólnych skal muzycznych, dopuszczał stosowanie ich wszystkich, podkreślając jednak, aby używano ich „w różny sposób” (Arystoteles 2001a, 224; por. Woerther 2008, 98-103; Szczeklik 2003, 81-86). Stagiryta był przekonany, że w wychowaniu moralnym człowieka ,pewne rodzaje muzyki wywierają wpływ ujemny" (Arystoteles 2001a, 222; por. Sachs 1988, 278-280).

Dlatego w swej Poetyce rozróżniał auletykę, czyli związaną z kultem Dionizosa muzykę śpiewaną przy akompaniamencie aulosu, która wprowadzała słuchacza w trans zmysłowy, oraz kitarystykę, czyli muzykę apollińską, wykonywaną przy wtórze kitary w duchu umiaru, harmonii i równowagi (por. Arystoteles 2001b). W Polityce krytycznie oceniał aulos, jako instrument niesprzyjający moralnemu uporządkowaniu, gdyż nie działa „,na uczucia kojąco”, powodując bardziej „wyzwolenie uczuć aniżeli pouczenie” (Arystoteles 2001a, 222). Jednak nie negował zupełnie aulosu, doceniając jego terapeutyczny wpływ na łagodzenie uczucia smutku (por. Fubini 1997, 57-58).

Akceptowanie przez Arystotelesa różnych rodzajów muzyki jest świadectwem jego realistycznej ,etyki spraw ludzkich”, czyli tego wszystkiego, z czym musi zmagać się człowiek, aby osiągnąć moralną doskonałość. Arystotelesowska koncepcja uzdrawiającego i etycznego znaczenia muzyki oraz jej wpływu na wychowanie budowana była na swoistej ,,wierze” w człowieka, $\mathrm{w}$ to, że pomimo doświadczanych problemów, sprzecznych niejednokrotnie uczuć i namiętności, pragnie on w głębi swej duszy dążyć do dobra (por. Stamou 2002, 3-16; Krasnodębski 2009, 26).

\section{Uzdrawiająca moc muzyki w ujęciu biblijnym na przykładzie króla Dawida}

Biblia jest jedynym w swoim rodzaju przekazem pamięci pokoleniowej, w którym zawarte są nie tylko treści religijne, ale także inspiracje będące źródłem kulturowego dziedzictwa ludzkości. Kardynał Gianfranco Ravasi stwierdza, że „Biblia jest wielkim kodem, czyli punktem odniesienia dla naszej kultury, którego nie można pominąć; gwiazdą polarną, którą wszyscy - wierzący i niewierzący - kierowali się, gdy szukali piękna, prawdy, dobra, a nawet odrzucali ją, aby błąkać się po bezdrożach” (Ravasi 2006, 10). Fundamentalnym pragnieniem człowieka Biblii było głębokie przeżywanie wiary w postawie uwielbienia Boga. Temu doświadczeniu towarzyszyła jednak świadomość, że samo słowo jest zbyt słabe, aby unieść tajemnicę Tego, który jest Trishagion - po trzykroć Święty (por. Szymik 2014, 22-23). Wówczas słowu przychodzi z pomocą muzyka. Trafnie ujął to kardynał Joseph Ratzinger: „Gdy człowiek nawiązuje kontakt z Bogiem, nie wystarcza już zwyczajne mówienie. Rozbudzane są wtedy sfery jego egzystencji, które spontanicznie stają się śpie- 
wem, co więcej - to, co posiada sam człowiek, okazuje się niewystarczające do wyrażenia tego, co pragnie powiedzieć, dlatego zaprasza całe stworzenie, żeby razem z nim stało się śpiewem" (Ratzinger 2012, 112). Jedną z takich „sfer egzystencji” ludzkiej jest doświadczenie choroby, gdy muzyka spotyka się z modlitwą, aby nieść ukojenie w cierpieniu.

Księga Rodzaju wiąże początki muzyki z najwcześniejszym etapem rozwoju ludzkości, potwierdzając, że należy ona do świata człowieka od samego początku. Wkrótce po opisie stworzenia w Genesis pojawia się rodowód pierwszego muzyka: „Lamek wziął sobie dwie żony. Imię jednej było Ada, a drugiej - Silla. Ada urodziła Jabala; on to był praojcem mieszkających pod namiotami i pasterzy. Brat jego nazywał się Jubal; od niego to pochodzą wszyscy grający na cytrze i na flecie" (Rdz 4,19-21). Znamienny jest fakt, że jego imię wywodzi się etymologicznie od hebrajskiego słowa oznaczającego róg barani (jobel), z którego wytwarzano prymitywne rogi sygnalizacyjne tzw. szofar (por. Begbie 2007, 63; Mowry 1999, 541; Rebić 2001, 12-13; McKinnon 2001, 274; Gądecki 2010, 112; Montagu 2006, 36-41). Biblijna relacja o Jubalu jako praojcu muzyki stanowi szczególne dowartościowanie tej dziedziny sztuki, a także dowód, że starożytni Izraelici uznawali ją za jedną z najistotniejszych wartości ludzkiego życia. Jednocześnie ten fragment Księgi Rodzaju jest symbolicznym potwierdzeniem roli muzyki w twórczym uzewnętrznianiu duchowych doświadczeń człowieka (por. Chrostowski 2018, 421-440; Kubies 2013, 3-17; Waloszek 1995, 119). Znamienne jest to, że symbolika muzyczna wpisana jest w topografię Ziemi Świętej. Starożytni Izraelici nadali bowiem Jezioru Galilejskiemu ze względu na jego kształt nazwę Genezaret (hebr. jam kinneret od słowa kinnor, które oznacza harfę lub lirę). Ponadto rabini uważali, że szum fal i kołysanych przez wiatr trzcin brzmi niczym dotykane przez harfistę struny (por. Radke 2021, 5).

Szczególnie znaczenie dla rozwoju biblijnej koncepcji terapeutycznej mocy muzyki miał król Dawid (ok. 1040-970 przed Chr.). Wnikliwą charakterystykę tej postaci nakreślił Benedykt XVI: „Dawid, niezwykły człowiek i teolog, to postać złożona, przeszedł on różne istotne doświadczenia życiowe. W młodości był pasterzem stada swego ojca, potem po zmiennych i niekiedy dramatycznych kolejach losu został królem Izraela, pasterzem ludu Bożego. Człowiek pokoju, prowadził liczne wojny; niestrudzenie i wytrwale szukał Boga, lecz zdradził Jego miłość, i co jest rzeczą charakterystyczną: zawsze szukał Boga, choć niekiedy ciężko grzeszył; jako pokorny pokutnik przyjął Boże przebaczenie, jak również karę Bożą, i pogodził się z bolesnym losem. Dawid był więc, pomimo wszystkich swoich słabości, «według serca Pana»

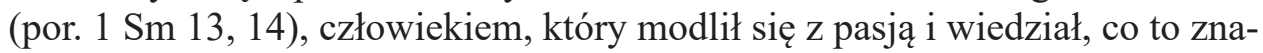
czy błagać i wielbić" (Benedykt XVI 2011, 47).

Król Dawid „błagał i wielbił” śpiewem i grą na instrumentach muzycznych. Ukazany jest na kartach Pisma Świętego nie tylko jako wybitny władca 
i wojownik, ale również jako utalentowany poeta i muzyk (por. 1 Sm 19,9),

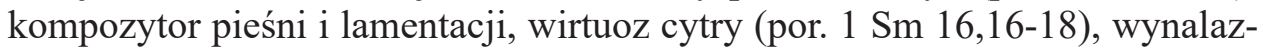
ca instrumentów (por. $2 \mathrm{Krn}$ 29,27; Am 6,5) oraz tancerz (por. 2 Sm 6,14-15) (Jurczak 2018, 91-106; Provenza 2014, 323-324; Motte 1990, 201-204). Muzyczny wymiar życia króla Dawida podkreślany był wielokrotnie w literaturze i sztuce, np. Dante Alighieri nazwał go w Boskiej komedii „Ducha Świętego lutnistą" (Dante 1965, 422) i „śpiewakiem, pierwszym między Pańskie sługi” (Dante 1965, 447). Jego bogate życie stało się inspiracją dla kompozytorów, czego przykładami są m.in. kantata David e penitente (KV 469) Wolfganga Amadeusza Mozarta, monumentalne oratoria Król Dawid Artura Honeggera i Dawid i Batszeba Ståle Kleiberga oraz opera Saul i Dawid Carla Nielsena.

$\mathrm{Na}$ teologiczny aspekt muzycznej działalności Dawida zwraca uwagę Druga Księga Samuela, nazywając go „śpiewakiem psalmów Izraela” (2 Sm 23,1). Król-muzyk miał świadomość, że jego śpiew jest znakiem działania Boga i sam to podkreślał: „Duch Pański mówi przeze mnie i Jego Słowo jest na moim języku" (2 Sm 23,2). Mocą muzyki pochodzącej z Bożego Ducha Dawid mógł przezwyciężać nawet działanie złego ducha, który sprowadzał na króla Saula ataki szału. Zawarte w Pierwszej Księdze Samuela opowiadanie dotyczące tego wydarzenia jest jednym $\mathrm{z}$ fundamentalnych tekstów biblijnych ukazujących terapeutyczną moc muzyki: „Saula natomiast opuścił duch Pański, a opętał zły duch, zesłany przez Pana. Odezwali się do Saula jego słudzy: «Oto dręczy cię zły duch [zesłany przez] Boga. Daj więc polecenie, panie nasz, aby słudzy twoi, którzy są przy tobie, poszukali człowieka dobrze grającego na cytrze. Gdy będzie cię męczył zły duch zesłany przez Boga, zagra ci i będzie ci lepiej». Saul odrzekł sługom: «Dobrze, wyszukajcie mi człowieka, który by dobrze grał, i przyprowadźcie go do mnie!»" (1 Sm 16,14-17). Dworzanie Saula, starając się pomóc królowi, wskazali jako remedium odprężenie, jakie przynosi słuchanie spokojnej i nastrojowej muzyki. Zaproponowali władcy leczenie za pomocą muzykoterapii (por. Pawlaczyk, Zakrzewska 2007, 251-252). W kulturze antycznej istniało powszechne przekonanie o terapeutycznej mocy muzyki, przynoszącej ulgę ludziom, którzy doświadczają melancholii, depresji i wewnętrznego niepokoju. Na starożytnym Bliskim Wschodzie znana była profesja dworskich muzyków, którzy nie tylko dostarczali rozrywki, ale także dbali o splendor uroczystości państwowych i religijnych. Dawid nie był jednak jednym z nich, a jego obecność na dworze Saula służyć miała ukojeniu wzburzonych emocji króla, pełniąc funkcję psychoterapeutyczną. Nękany przez napady szału władca posłuchał rady dworzan i polecił sprowadzić Dawida (por. 1 Sm 16,17-19; Chrostowski 2014, 19).

Efekty zastosowanej przez Dawida muzykoterapii były początkowo bardzo pozytywne, co poświadcza Pierwsza Księga Samuela: „A kiedy zły duch zesłany przez Boga napadał na Saula, brał Dawid cytrę i grał. Wtedy Saul 
doznawał ulgi, czuł się lepiej, a zły duch odstępował od niego" (1 Sm 16,23). Gra Dawida na cytrze ${ }^{1}$ przynosiła królowi psychiczne odprężenie i łagodziła rodzące się w nim napięcia. Uspokajała także jego agresję, gdy król przestawał nad sobą panować i popadał w szaleńcze uniesienie. Pojawiające się w analizowanym tekście biblijnym wzmianki o ,napadach złego ducha zesłanego przez Boga" to starożytny sposób określania choroby psychicznej (obłędu) lub opętania. W świetle współczesnej wiedzy z zakresu psychiatrii zachowanie władcy zostałoby prawdopodobnie zaklasyfikowane jako rodzaj schizofrenii lub przypadek psychozy maniakalno-depresyjnej, którą cechują silne zaburzenia afektywne, wahania nastrojów, a nade wszystko cykliczne fazy depresji. Osoba chora zagraża wówczas samej sobie oraz otoczeniu (Dziadosz 2015 42-48; Ben-Noun 2013, 111-112). Można także zinterpretować objawy Saula jako zaburzenia urojeniowe, wskazujące na paranoję prześladowczą (Rosińska 2016, 130; Williams, Roux 2011, 1-6).

O pogłębiającej się chorobie Saula świadczy dalszy rozwój wypadków. Po pewnym czasie, z powodu zazdrości o sukcesy militarne i społeczną popularność młodego Dawida, stan Saula się pogorszył. Muzykoterapia przestała być skuteczna. Tak relacjonuje to autor Pierwszej Księgi Samuela: „A oto nazajutrz zły duch, zesłany przez Boga, opanował Saula, który popadł w szał wewnątrz swojego domu. Dawid tymczasem grał na cytrze, tak jak każdego dnia. Saul trzymał w ręku dzidę. I rzucił Saul dzidą, bo myślał: «Przybiję Dawida do ściany». Lecz Dawid dwukrotnie tego uniknął. Saul bardzo bał się Dawida: bo Pan był z nim, a od Dawida odstąpił" (1 Sm 18,10-12). Waldemar Chrostowski zauważa: „Silnie kontrastowe przedstawienie obu postaci - Dawid trzyma w ręku cytrę, a Saul dzidę - stanowi wymowne zobrazowanie kondycji zdrowia i choroby. Drastycznie zmieniające się samopoczucie Saula wskazuje na objawy schizofrenii" (Chrostowski 2014, 20). Zachowanie Saula ma w cytowanym tekście znaczenie symboliczne. Dzidą, która jako królewski atrybut była znakiem bohaterskich czynów, Saul próbował pozbawić życia bezbronnego młodzieńca, który grał na cytrze. Dzida jako symbol wojny zostaje zestawiona z cytrą oznaczającą piękno i pokój (por. Rosińska 2016, 124).

Ta symbolika wskazuje nie tylko na terapeutyczny, ale także teologiczno-moralny wymiar wykonywanej przez Dawida muzyki, która miała na celu wyzwolenie i oczyszczenie od zła, czyli działanie katarktyczne podobne do egzorcyzmu. Ojcowie Kościoła i średniowieczni teologowie (m.in. św. Ni-

\footnotetext{
1 „Cytra" ta była prawdopodobnie rodzajem liry (hebr. kinnor), instrumentu strunowego składającego się z pudła rezonansowego i dwóch ramion przedzielonych poprzeczką, do której przymocowane było od trzech do 12 strun. Instrument był takiej wielkości, że można go było trzymać w jednej ręce, podczas gdy druga uderzała w struny. Tego typu lirę odnaleziono podczas prac archeologicznych w kananejskim mieście Megiddo. (Por. Walton, Matthews, Chavalas 2005, 334-335; Begbie 2007, 62; McKenzie 2000, 56-57).
} 
cetasz z Remezjany, św. Izydor z Sewilli, św. Beda Czcigodny, Honoriusz z Autun, Hugo od św. Wiktora) interpretowali stan Saula jako rodzaj opętania demonicznego, a lirę Dawida przyrównywali symbolicznie do Krzyża Chrystusa, który przyniósł człowiekowi wyzwolenie z mocy złego ducha (por. Howe 2016, 539-559). Wszystko to sprawia, że „Dawid może [...] słusznie uchodzić za prekursora muzykoterapii i patrona muzykoterapeutów” (Biel 2018, 27).

Uzdrawiająca moc tworzonej przez Dawida muzyki znalazła swe odzwierciedlenie w Księdze Psalmów. Według tradycji żydowskiej, król-muzyk jest autorem ponad połowy psalmów (w tekście masoreckim przypisuje się mu 74 psalmy; Kselmann, Barré 2001, 482). Psatterz wyraża ludzkie doświadczenie, z różnymi jego odcieniami i całą gamą uczuć, które towarzyszą egzystencji człowieka. Splatają się w niej radość i cierpienie, pragnienie Boga i dostrzeganie własnej niegodności, szczęście i poczucie opuszczenia, ufność w Bogu i bolesna samotność, pełnia życia i lęk przed śmiercią. Cały etos człowieka wiary zespala się w tych muzycznych modlitwach w wielką syntezę. Dlatego lud Izraela, a następnie Kościół, przyjął Księgę Psalmów jako uprzywilejowane świadectwo relacji pomiędzy człowiekiem a Bogiem. Swoista „semiotyka teologiczna” psalmów sprawia, że możemy nimi nie tylko rozmawiać z Bogiem, ale także uczyć się, kim jest Bóg. To zaś kształtuje w nas pełnię człowieczeństwa. Psalmy są szczególnym przejawem duchowości biblijnej, w której każdy może rozpoznać samego siebie. Przekazują one w poetycko-muzycznej formie uniwersalne doświadczenie szczególnej bliskości z Bogiem, do której powołany jest człowiek (Benedykt XVI 2011, 45). Księga Psalmów jako biblijny ,śpiewnik” wyraża niezwykle bogate treści teologiczno-moralne. Dotyczą one historii człowieka, który od momentu stworzenia poprzez codzienne zmagania, doświadczając zarówno radości, jak i cierpienia, nieustannie dąży do spotkania z Bogiem. Każdy, „kto odczuwa pragnienie”, może dostąpić pełni tego uzdrawiającego spotkania w Jezusie, który jest „Odroślą i Potomstwem Dawida” (por. Ap 22,16-17), a w „Jego ranach jest nasze zdrowie" (Iz 53,5; por. 1 P 2,24).

\section{3. Średniowieczna muzykoterapia w ujęciu św. Hildegardy z Bingen}

Myśl antyczna wywarła wpływ na kształtowanie się średniowiecznej refleksji filozoficznej i teologicznej dotyczącej terapeutycznego wymiaru muzyki. Cechą charakterystyczną teorii muzyki wieków średnich było przekonanie o moralnym oddziaływaniu muzyki. Wątek ten powracał w większości traktatów o muzyce tego okresu. Podkreślano w nich, że muzyka zdolna jest kształtować obyczaje, wpływać na ludzki charakter oraz uzdrawiać chorych. 
Świadczy to wyraźnie o tym, że średniowieczne koncepcje muzyki były kontynuacją antycznej nauki o etosie, a nawet swoistą recepcją myśli starożytnych filozofów w duchu chrześcijańskim (por. Thaut 2015, 151-152; Morawski 1979, 30-31).

Ponadto w tej epoce rozwinęła się wizja muzyki kościelnej jako ziemskiego odzwierciedlenia niebiańskiego śpiewu aniołów i duchowego w nim uczestnictwa. Stąd pochodziła jej szczególna moc oczyszczająca, terapeutyczna oraz wykorzystywana do odpędzania złych duchów (por. Gillette 2014-2015, 95118; Huck 2003, 99-119; Matusiak 2000, 55-59). Ośrodkami refleksji naukowej oraz praktyki w zakresie muzykoterapii były w wiekach średnich klasztory. W centrach monastycznych powstawały wspaniałe, najczęściej anonimowe, dzieła muzyki sakralnej, pełne uroczystej powagi, różnorodności i duchowego bogactwa. Zawarte w śpiewach gregoriańskich partie solowe oraz chóralne do dnia dzisiejszego zachwycają niepowtarzalnym klimatem modlitwy, wznosząc ludzkie myśli ku Bogu i przywracając harmonię duchową (Tyrała 2019, 72-78; Wiśniewski 2014, 103-118; Mahrt 2006, 5-14).

Szczególnym świadectwem średniowiecznego przekonania o uzdrawiającym oddziaływaniu muzyki są bogate $\mathrm{w}$ treść teologiczną i medyczną dzieła św. Hildegardy z Bingen (1098-1179) - doktora Kościoła, benedyktynki, kompozytorki, lekarki i wizjonerki. Ze względu na szeroki zakres swej działalności uważana jest ona za jedną z najwybitniejszych indywidualności średniowiecznej Europy. Ta niezwykła kobieta od dzieciństwa doświadczała obecności wewnętrznego światła, które było źródłem jej teologicznych intuicji oraz prorockiego posłannictwa. Te szczególne charyzmaty sprawiły, że św. Hildegardę określa się jako „Sybillę Renu” i prophetissa teutonica (por. Bafia 2020, 9-21; Bent, Pfau 2001, 493-499). Charakteryzując twórczość tej świętej, Benedykt XVI zauważa: „Mistyczne wizje Hildegardy zawierają bogate treści teologiczne. Odnoszą się do zasadniczych wydarzeń dziejów zbawienia, a ich język jest przede wszystkim poetycki i symboliczny" (Benedykt XVI 2010, 43). Wizje dotyczące głównych wydarzeń w historii zbawienia wyrażała ona poprzez pełną alegorii poezję i muzykę, koncentrując się zwłaszcza na Chrystusie, który nadaje cel całemu dziełu stworzenia. W swoich pismach o charakterze apokaliptycznym ukazywała kosmiczny dramat walki dobra ze złem oraz ostateczne przeznaczenie człowieka w świetle Bożego objawienia. Ten etyczny i eschatologiczny kontekst pozwala lepiej zrozumieć jej przekonania o terapeutycznym oddziaływaniu muzyki (por. Giannacco 2020, 43-53).

Nawiązując do jednego z dzieł św. Hildegardy, zatytułowanego Liber vitae meritorum („Księga zasług życia”), Benedykt XVI zwrócił uwagę na zawarte w nim treści teologiczno-moralne: „Głównym tematem tekstu jest relacja między cnotami i wadami; człowiek powinien zatem codziennie stawiać czoło wyzwaniu, jakim są wady, które oddalają go od drogi do Boga, oraz 
cnót, sprzyjających temu dążeniu. Jest to zachęta do wystrzegania się zła, by chwalić Boga oraz by po cnotliwym życiu wkroczyć w życie «pełne radości»" (Benedykt XVI 2010, 43). Perspektywa moralna ściśle złączona była z jej bogatą działalnością muzyczną. Odnosząc się do tego, Benedykt XVI stwierdził: „Hildegarda zajmowała się [...] muzyką, jako że była obdarzona talentem artystycznym. Komponowała m.in. hymny, antyfony i pieśni [...]. Wykonywano je radośnie w jej klasztorach, szerząc pogodną atmosferę, a przetrwały one aż do naszych czasów. Dla niej całe stworzenie jest symfonią Ducha Świętego, który sam jest radością i weselem” (Benedykt XVI 2010, 43-44).

Święta Hildegarda skomponowała muzykę i teksty do ponad 77 utworów liturgicznych, które zostały zebrane w dziele pt. Symphonia harmonia e caelestium revelationum (,Symfonia harmonii objawień niebieskich”). Wśród nich znajdują się 43 antyfony, 18 responsoriów, siedem sekwencji, cztery hymny, jedno Kyrie, jedno Alleluja oraz trzy utwory trudne do jednoznacznego zakwalifikowania formalnego. Zastosowała w nich oryginalne rozwiązania melodyczne, które wykazują cechy wysoce indywidualne i tylko w nieznacznym stopniu związane są ze śpiewem gregoriańskim. Cechuje je bogata melizmatyka i szeroki zakres dźwiękowy, co sprawia, że jej twórczość należy do najwybitniejszych osiągnięć muzycznych średniowiecza (por. Cagnoli 2008, 5-26; Bafia 2020, 132; Morawski 1993, 210-211). Kompozycje te nie tylko uświetniały klasztorną liturgię, ale także służyły do leczenia chorych. Uważano, że wraz z innymi środkami medycznymi wpływają na rozluźnienie mięśni, koją nerwy słuchaczy, a nawet pomagają m.in. w łagodzeniu objawów chorób psychosomatycznych, skórnych, stresu pourazowego, autyzmu czy epilepsji (por. Romaní, Romaní 2017, 538-543; Ranft 2014, 107-115; Brigo, Trinka, Brigo, Bragazzi, Ragnedda, Nardone, Martini 2018, 135-143).

W muzycznej spuściźnie Sybilli Renu szczególne miejsce zajmuje dramat liturgiczny, zatytułowany Ordo Virtutum (,Zastęp cnót”), który jest rodzajem moralitetu o charakterze psychomachii (od gr. psyche - 'dusza', machia 'walka'). Dzieło to jest jednym z pierwszych rozbudowanych utworów dramatycznych średniowiecza. Święta Hildegarda w muzyczno-poetyckiej formie zawarła w nim głębokie przesłanie teologiczno-moralne, dotyczące odwiecznego zmagania pomiędzy dobrem a złem, które rozgrywa się w człowieku. W tej wewnętrznej walce ludzką duszę wspierają cnoty, które pomagają jej pokonać zło. Moralno-dydaktyczna treść zbliża Ordo Virtutum do średniowiecznych dramatów liturgicznych, od których różni się jednak psychologiczno-mistycznym ujęciem zagadnienia (por. Hildegarda z Bingen 2009, 108-123; Gardiner 2019, 1-49).

Etyczne przesłanie zawarte w muzyce komponowanej przez św. Hildegardę było ściśle związane z jej głębokim przekonaniem o uzdrawiających właściwościach przyrody oraz muzyki, którą uważała za integralną część świata 
stworzonego. Wszechświat był dla niej hymnem, symfonią na cześć Boga. Dla Sybilli Renu w całym dziele stworzenia, w drzewach, w ziołach, a nawet w kamieniach szlachetnych ukryte były moce uzdrawiające, z których człowiek mógł korzystać zgodnie z wolą Bożą. Jednym z wiodących wątków myśli św. Hildegardy była neopitagorejska i neoplatońska idea człowieka jako mikrokosmosu, odzwierciedlającego strukturę wszechświata pojmowanego jako makrokosmos. Koncepcje antyczne Sybilla Renu interpretowała jednak w sposób twórczy i oryginalny, odnosząc się do Biblii i pism ojców Kościoła (por. Bafia 2020, 122-133; Obolevitch 2013, 21-28; Kowalewska 2003, 454).

Niezwykle ważne i często analizowane przez św. Hildegardę zagadnienie stosunku duszy do ciała mistyczka przedstawia w charakterystycznym dla niej obrazowym stylu (por. Wieczorek 2016, 201-222). Dusza jest siłą ożywiającą i poruszającą ludzkie ciało. Sposób działania duszy w ciele św. Hildegarda porównuje w Scivias do soku drzewa, który rozlewa się na wszystkie jego części, zapewniając im zieleń i wzrost (por. Hildegarda z Bingen 2011, 213). Antropologiczna myśl św. Hildegardy zgodna jest z chrześcijańską zasadą corpore et anima unus. Człowiek jest w swej naturze zarówno cielesny, jak i duchowy. Jego ciało i dusza są ze sobą ściśle złączone. Dlatego jeśli choruje ciało, choruje też i dusza. Najpierw zatem trzeba uleczyć w człowieku duszę, a następnie uzdrowione będzie również jego ciało (Bafia 2020, 183-185; Wieczorek 2013, 259-268; Callahan 2000, 151-164).

„Uleczeniu duszy” służyła muzyka, która według św. Hildegardy obejmowała całość rzeczywistości, zarówno w wymiarze boskim, jak i ludzkim. Symbolika muzyczna była ściśle złączona z jej myślą teologiczną. Sybilla Renu odwoływała się do muzyki, rozważając nie tylko tajemnicę Trójcy Świętej, ale także znaczenie aniołów, złych duchów, świętych, człowieka, zwierząt oraz przyrody nieożywionej. Wszechświat według niej był harmonią i symfonią. Jednak jej teologiczna interpretacja muzyki przenikającej całe stworzenie wykraczała daleko poza antyczną teorię harmonii sfer. Hildegarda pojmowała rzeczywistość materialną i duchową jako dźwięczący instrument, z którego wydobywają się nieustannie różnorodne tony. Każdy element bytu, zarówno rzeczy, jak i istoty żywe, ma określony ton, który współbrzmi z wielką symfonią stworzenia. Właściwe sobie tony mają także poszczególne epoki historii zbawienia. Źródłem odwiecznej harmonii universum jest Bóg, który na przestrzeni wieków wyznacza każdemu miejsce w wielkim chórze stworzenia. Według Sybilli Renu pierwszym i najważniejszym tonem muzyki świata, który nigdy nie przemija i od którego wszelkie inne pochodzą, jest głos samego Boga. Tym tonem powołał On do bytu wszechświat i nieustannie podtrzymuje go w istnieniu (por. Kowalewska 2006, 107; Matusiak 2003, 35-41).

Dysonans w harmonii wszechświata pojawił się za sprawą zbuntowanych przeciwko Bogu upadłych aniołów - Szatana i służących mu duchów ciemno- 
ści, do których św. Hildegarda odnosiła się z wielką odrazą. Nie mają oni żadnej właściwej sobie muzyki, zaś jedynymi odgłosami, jakie wydają z siebie podczas egzorcyzmów, są krzyki i bluźnierstwa. Wyraz tego odnaleźć można w utworze dramatycznym Ordo virtutum, gdzie partie diabła są pozbawione muzyki, a na śpiew cnót odpowiada on demonicznym wrzaskiem (strepitus diaboli). Szatan nie może znieść piękna muzyki, gdyż jest przeciwnikiem wszelkiej harmonii. Dlatego dąży on do tego, aby muzyka zmieniła się w totalną dysharmonię. W ten sposób świat, będący skomponowaną przez Boga symfonią, mógłby pogrążyć się w chaosie (por. Matusiak 2003, 59-72; Kowalewska 2003, 453; Bafia 2020, 222-231).

Niezwykle interesujące pod względem teologiczno-moralnym są także spostrzeżenia św. Hildegardy dotyczące wpisanej w naturę ludzką zdolności do uczestniczenia $\mathrm{w}$ muzyce niebiańskiej. W jej poglądach uwidacznia się właściwe dla średniowiecza przekonanie o muzycznej naturze świata aniołów ${ }^{2}$. Według Sybilli Renu, muzyka, jako naśladowanie kosmicznej harmonii sfer, pośredniczy między Bogiem a ludźmi i jest najwspanialszym sposobem służenia $\mathrm{Mu}$, a także środkiem ekspresji ludzkiej duszy, przejawiającej się w modlitwie. Człowiek, stworzony na obraz i podobieństwo Boże, ma symfoniczną duszę, zdolną do współbrzmienia z chórami aniołów i z harmonią świata nadprzyrodzonego. Dusza człowieka jest symfoniczna (symphonialis est anima), czyli harmonijna, współbrzmiąca, przenikająca ciało i zaprowadzająca w nim porządek. Święta Hildegarda rozumiała pojęcie „symfonii” jako zgodnego współbrzmienia, które przywraca harmonię duszy i ciała, stając się źródłem uzdrowienia (por. Hildegarda z Bingen 2003, 160; Obolevitch 2013, 27-28; Matusiak 2003, 51-57; Kowalewska 2007, 153-162).

Dla św. Hildegardy muzyka była wspomnieniem utraconego raju, o czym pisze m.in. w Liście 23 do prałatów mogunckich (por. Hildegarda z Bingen 2003, 155-161). Grzech pierwszych rodziców sprawił, że człowiek zniszczył w sobie zdolność uczestniczenia w muzyce niebiańskiej. Według Sybilli Renu Adam przed upadkiem znał pieśni aniołów oraz miał głos dźwięczny jak ton monochordu. Po grzechu ta niebiańska muzyka została w nim stłumiona. Jednak Bóg w swym miłosierdziu pozostawił mu zdolność śpiewu i muzykowania jako wyraz tęsknoty za utraconym rajem i przypomnienie stanu przed grzechem pierworodnym (por. Garrido, Davidson 2019, 86-87; Flynn 2011, 203-229; Kowalewska 2003, 456).

Przez to Stwórca nie przestaje wzywać człowieka do współuczestniczenia w symfonii świata. Świadectwem tego jest towarzyszące ludziom od same-

${ }^{2}$ Niezwykłe bogactwo teologiczno-muzycznej symboliki związanej z aniołami odnaleźć można w słynnym tryptyku Sąd ostateczny Hansa Memlinga, który pochodzi z bazyliki Mariackiej w Gdańsku (obecnie przechowywany jest w Muzeum Narodowym w Gdańsku; por. Odoj 2018, 163-173). 
go początku zamiłowanie do twórczości muzycznej i słuchania harmonijnej muzyki, które wypełnia duszę tęsknotą za Bożym światem (por. Matusiak 2003, 86-90). Dzieło odkupienia dokonane przez Chrystusa sprawiło, że człowiek znowu może śpiewać wraz z aniołami pieśń chwały. W chwili paruzji, gdy Chrystus przyjdzie na końcu czasów, ludzie ponownie uczestniczyć będą w niebiańskiej symfonii (por. Matusiak 2003, 109-142). Te teologiczne refleksje przenikały terapeutyczną koncepcję muzyki św. Hildegardy z Bingen, sprawiając, że uznawana jest ona za jedną z najwybitniejszych prekursorek muzykoterapii.

\section{Zakończenie}

Terapeutyczne znaczenie muzyki jest zagadnieniem wieloaspektowym. Aby zrozumieć jego podstawy, istotna jest refleksja o charakterze filozoficznym i teologicznym. Już w starożytności istniało powszechne przekonanie o uzdrawiającym oddziaływaniu muzyki. Świadectwem tego jest spuścizna szkoły pitagorejskiej oraz wielkich myślicieli antycznych, zwłaszcza Platona i Arystotelesa. Ich badaniom zawdzięczamy pierwsze sklasyfikowanie oraz systematyczne wykorzystanie w praktyce określonych rodzajów muzyki, mogących oddziaływać na człowieka. Jednym z podstawowych założeń antycznego pojmowania muzyki było przekonanie, że może nas ona uspokajać, pocieszać, odrywać od codziennych trosk, a także pobudzać i wprowadzać w stan uniesienia, a nawet szału. W ten sposób greccy myśliciele nadali filozoficzne podstawy sięgającemu zamierzchłej starożytności przeświadczeniu o terapeutycznej mocy muzyki i jej związku z medycyną. Sformułowali oni katartyczną (gr. katharsis) koncepcję muzyki jako oczyszczającego lekarstwa dla ludzkiej duszy, nadając jej funkcję etyczną i wychowawczą. Wzmianki o uzdrawiającym charakterze muzyki można odnaleźć również w przekazach biblijnych. Najbardziej znacząca jest tu postać króla Dawida - władcy, wojownika, ale także niezwykle uzdolnionego poety, kompozytora i muzyka, który grą na cytrze uspokajał ataki szału Saula. Starożytna idea muzycznego katharsis, czyli oczyszczenia obejmującego różne aspekty ludzkiego życia, stała się źródłem średniowiecznych koncepcji teologicznych i medycznych, których najbardziej znaczącą reprezentantką jest św. Hildegarda z Bingen. Zarówno tradycja antycznej myśli greckiej, jak i przekazy biblijne oraz ich teologiczna recepcja w wiekach średnich, stanowią korzenie europejskiej kultury, bez których trudno byłoby zrozumieć rozwój muzykoterapii w następnych epokach. 


\section{PHILOSOPHICAL AND THEOLOGICAL SOURCES OF MUSIC THERAPY IN ANTIQUITY AND THE MIDDLE AGES}

\section{SUMMARY}

The therapeutic importance of music is a multi-faceted issue. To understand its basics, a philosophical and theological reflection is essential. Already in antiquity, there was a common belief that music had a healing effect. This is evidenced by the legacy of the Pythagorean school and great ancient thinkers, especially Plato and Aristotle. We owe their research to the first classification and systematic use in practice of certain types of music that can affect humans. One of the basic assumptions of the ancient understanding of music was the belief that it can soothe us, console us, distract us from everyday worries, as well as stimulate and lead us into a state of elation, and even madness. In this way, Greek thinkers gave a philosophical foundation to the ancient antiquity belief in the therapeutic power of music and its relationship with medicine. They formulated a cathartic (Greek katharsis) concept of music as a cleansing medicine for the human soul, giving it an ethical and educational function. Mentions about the healing nature of music can also be found in biblical accounts. The most significant figure here is King David - a ruler, warrior, but also an extremely talented poet, composer and musician, who by playing the zither soothed the attacks of Saul's frenzy. The ancient idea of musical katharsis, i.e. purification involving various aspects of human life, became the source of medieval theological and medical concepts, of which St. Hildegard of Bingen.

Keywords: music therapy, philosophy of music, theology of music, king David, St. Hildegard of Bingen

Słowa kluczowe: muzykoterapia, filozofia muzyki, teologia muzyki, król Dawid, Hildegarda $z$ Bingen

\section{WYKAZ SKRÓTÓW}

KKK - Katechizm Kościoła katolickiego.

\section{BIBLIOGRAFIA}

Arystoteles. 2001a. Polityka. W: Dzieła wszystkie, t. 6, 7-226. Warszawa: PWN. Arystoteles. 2001b. Poetyka. W: Dzieła wszystkie, t. 6, 563-626. Warszawa: PWN.

Bafia, Stanisław. 2000. Hildegarda z Bingen 1098-1179. Nie o medycynie i muzyce. Górna Grupa: Verbinum. 
Begbie, Jeremy. 2007. Resounding Truth: Christian Wisdom in the World of Music. Grand Rapids: Baker Academic.

Belfiore, Elisabeth. 1992. Tragic Pleasures. Aristotle on Plot and Emotion. New Jersey: Princeton University Press.

Benedykt XVI. 2010. Św. Hildegarda z Bingen [II] (8.09.2010). L'Osservatore Romano 31(10), 43$-44$.

Benedykt XVI. 2011. W Psalmach Słowo Boże staje się słowem modlitwy (22.06.2011). L'Osservatore Romano 32(8-9), 45-47.

Ben-Noun, Liubov. 2013. Music Therapy in the Bible. Medical Research in Biblical Times from the Viewpoint of Contemporary Perspective. Beer-Sheva: Ben-Gurion University of the Negev.

Bent, Ian, Marianne Pfau. 2001. Hildegard of Bingen. W: The New Grove Dictionary of Music and Musicians, red. Stanley Sadie, t. 11, 493-499. New York: Oxford University Press.

Biel, Stanisław. 2018. Dawid. Medytacje biblijne. Kraków: WAM.

Bramorski, Jacek. 2012. Pieśń nowa czlowieka nowego. Teologiczno-moralne aspekty muzyki w świetle myśli Josepha Ratzingera - Benedykta XVI. Gdańsk: Wydawnictwo Akademii Muzycznej im. Stanisława Moniuszki w Gdańsku.

Brigo, Francesco, et al. 2018. Epilepsy in Hildegard of Bingen's writings: A Comprehensive Overview. Epilepsy\&Behavior 80, 135-143. DOI: https://doi.org/10.1016/j.yebeh.2017.10.002

Cagnoli, Bruno. 2008. Misticismo, poesia e musica in Hildegard von Bingen (1098-1179). Attidella Accademia roveretana degli Agiati 258(8) vol. 8, A, fasc. 2, 5-26.

Callahan, Christopher. 2000. Music in Medieval Medical Practice: Speculations and Certainties. College Music Symposium 40, 151-164.

Cates, Brian. 2013. On the Power of Music: Using ,Cosmos' and ,Anthropos' to Articulate a HolisticApproach to Discussing the Power of Music. Musical Offerings 4(1), 31-41. DOI: 10.15385/ jmo.2013.4.1.3

Chrostowski, Waldemar. 2014. Chorzy psychicznie w Biblii. Collectanea Theologica 84(1), 5-29.

Chrostowski, Waldemar. 2018. Kiedy Bóg płacze ... oraz inne studia. Warszawa: Vocatio.

Dante Alighieri. 1965. Boska Komedia. Warszawa: PIW.

David, Rosalie. 2008. The Ancient Egyptian Medical System. W: Egyptian Mummies and Modern Science, red. Rosalie David, 181-194. Cambridge: Cambridge University Press.

Dembiński, Bogdan. 2010. Późny Platon i Stara Akademia. Kęty: Wydawnictwo Marek Derewiecki.

Dziadosz, Dariusz. 2015. Szaleństwo Saula. Obłęd, opętanie czy polityczna intryga?. Ethos 28(2), 31-53. DOI: $10.12887 / 28-2015-2-110-04$

Eliade, Mircea. 1988. Historia wierzeń i idei religijnych, t. 1. Warszawa: PAX.

Flynn, William. 2011. Singing with the Angels: Hildegard of Bingen's Representations of Celestial Music. W: Conversations with Angels. Essays Towards a History of Spiritual Communication, 1100-1700, red. Joad Raymond, 203-229. New York: Palgrave Macmillan.

Fubini, Enrico. 1997. Historia estetyki muzycznej. Kraków: Musica Iagellonica.

Gajda, Janina. 1996. Pitagorejczycy. Warszawa: Wiedza Powszechna.

Gardiner, Michael. 2019. Hildegard von Bingen's Ordo Virtutum. A Musical and Metaphysical Analysis. Abingdon: Routledge.

Garrido, Sandra i Jane Davidson. 2019. Music, Nostalgia and Memory: Historical and Psychological Perpectives. Cham: Palgrave Macmillan.

Gądecki, Stanisław. 2010. Muzyka według Biblii. W: Credidimus caritati, red. Maciej Olczyk, Paweł Podeszwa, 111-126. Gniezno: Prymasowskie Wyższe Seminarium Duchowne.

Giannacco, Valentina. 2020. L'ideale di santità di Ildegarda di Bingen (1098-1179). De Medio Aevo, 14, 43-53. DOI: http://dx.doi.org/10.5209/dmae.69895.

Gillette, Amy. 2014-2015. Depicting the sound of silence: angels' music and "angelization" in medievalsacred art. Imago Musicae 27-28, 95-125

Gioia, Ted. 2006. Healing Songs. Durham: Duke University Press. 
Góźdź, Krzysztof. 2010. Monizm czy dualizm antropologiczny?. Studia Theologica Varsaviensia 48(2), 45-62.

Halliwell, Stephen. 2003. La psychologie morale de la katharsis. Les Études Philosophiques 4, 499-517 .

Hildegarda z Bingen. 2003. List 23 do prałatów mogunckich. W: Hildegarda z Bingen. Teologia muzyki, red. Błażej Matusiak, 155-161. Kraków: Homini.

Hildegarda z Bingen. 2011. Scivias. Kraków-Tyniec: Wydawnictwo Benedyktynów.

Hildegarda z Bingen. 2009. Ordo Virtutum - Zastęp Cnót. Studia Antyczne i Mediewistyczne 7, 108-123 .

Howe, Blake. 2016. Saul, David, and Music's Ideal Body. W: The Oxford Handbook of Music and Disability Studies, red. Blake Howe, et al., 539-559. Oxford and New York: Oxford University Press.

Huck, Oliver. 2003. The Music of the Angels in Fourteenth- and Early Fifteenth-Century Music. Musica Disciplina 53, 99-119.

Huffman, Carl. 2009. The Pythagorean Conception of the Soul from Pythagoras to Philolaus. W: Body and Soul in Ancient Philosophy, red. Dorothea Frede, Burkhard Reis, 21-44. Berlin: De Gruyter.

Jaeger, Werner 2001. Paideia, Formowanie człowieka greckiego. Warszawa: Aletheia.

James, Jamie. 1996. Muzyka sfer. O muzyce, nauce i naturalnym porządku świata. Kraków: Znak.

Jurczak, Damian. 2018. Muzyka w Starym Testamencie na przykładzie króla Dawida. W: Psychologiczne, pedagogiczne i teologiczne oblicza twórczości muzycznej, red. Piotr Kierpal, Emilia Lichtenberg-Kokoszka, 91-106. Opole: Nakład własny redaktorów.

Katechizm Kościoła katolickiego. 2002. Poznań: Pallottinum.

Klimowski, Piotr. 2015. Kategoria obecności w kontekście religii. Racjonalia 5, 85-106. DOI: http:// dx.doi.org/10.15633/r.1810

Kowalewska, Małgorzata. 2003. Hildegarda z Bingen. W: Powszechna encyklopedia filozofii, red. Andrzej Maryniarczyk, t. 4, 452-457. Lublin: Polskie Towarzystwo Tomasza z Akwinu.

Kowalewska, Małgorzata. 2006. Ku symfonii chwały. Rola muzyki w myśli Hildegardy z Bingen. Ethos 19(1-2), 103-117.

Kowalewska, Małgorzata. 2007. Bóg - Kosmos - Człowiek w twórczości Hildegardy z Bingen. Lublin: Wydawnictwo Uniwersytetu Marii Curie Skłodowskiej w Lublinie.

Krasnodębski, Mikołaj. 2009. Arystotelesa teoria wychowania, Opieka, wychowanie, terapia 1-2, $15-27$.

Kselmann, John, Michael Barré. 2001. Księga Psalmów. W: Katolicki komentarz biblijny, red. Raymond E. Brown, Joseph A. Fitzmyer, Roland E. Murphy, 481-524. Warszawa: Vocatio.

Kubies, Grzegorz. 2013. Jubal, pierwszy muzyk w dziejach świata?. Muzyka 58(2), 3-17.

Mahrt, William. 2006. Gregorian Chant as a Paradigm of Sacred Music. Sacred Music 133(1), 5-14.

Mathiesen, Thomas. 1984. Harmonia and Ethos in Ancient Greek Music. The Journal of Musicology 3(3), 264-279.

Matusiak, Błażej. 2000. Śpiew aniołów, Teofil 14(3), 55-59.

Matusiak, Błażej. 2003. Hildegarda z Bingen. Teologia muzyki, Kraków: Homini.

McClary, Rebecca. 2007. Healing the Psyche through Music, Myth, and Ritual. Psychology of Aesthetics, Creativity, and the Arts, 1(3), 155-159. DOI: https://doi.org/10.1037/19313896.1.3.155

McKenzie, Steven. 2000. King David: A Biography. Oxford and New York: Oxford University Press.

McKinnon, James. 2001. Jubal. W: The New Grove Dictionary of Music and Musicians, red. Stanley Sadie, t. 13, 274. New York: Oxford University Press.

Montagu, Jeremy. 2006. Instrumenty muzyczne Biblii. Kraków: Homini.

Morawski, Jerzy. 1979. Teoria muzyki w średniowieczu. Wybrane zagadnienia. Warszawa: Akademia Teologii Katolickiej. 
Morawski, Jerzy. 1993. Hildegarda z Bingen. W: Encyklopedia muzyczna PWM, t. 4, red. Elżbieta Dziębowska. 210-211, Kraków: PWM.

Motte, Rene. 1990. Dawid. W: Stownik teologii biblijnej, red. Xavier Léon-Dufour, 201-204. Poznań: Pallottinum.

Mowry, Lucetta. 1999. Muzyka i instrumenty muzyczne. W: Stownik wiedzy biblijnej, red. Bruce M. Metzger, Michael D. Coogan, 540-542. Warszawa: Vacatio.

Obolevitch, Teresa. 2013. Człowiek jako mikrokosmos w ujęciu Hildegardy z Bingen. Rocznik Filozoficzny Ignatianum 19(1), 7-36.

Odoj, Wojciech. 2018. Musical Motifs in Hans Memling's Last Judgment (The NationalMuseum in Gdańsk, c.1471). Medieval Studies / Studia z Dziejów Średniowiecza, 22, 163-173. DOI: https:// doi.org/10.4467/25442562SDS.18.011.9813

Pawlaczyk, Bogusław i Małgorzata Zakrzewska. 2007. Biblia a medycyna. Poznań: Księgarnia Świętego Wojciecha.

Platon. 2001. Państwo. Kęty: Wydawnictwo Marek Derewiecki.

Podbielski, Henryk. 2004. Katharsis. W: Powszechna encyklopedia filozofii, t. 5, red. Andrzej Maryniarczyk, 546-551. Lublin: Polskie Towarzystwa Tomasza z Akwinu.

Provenza, Antonietta. 2014. Soothing Lyres and Epodai: Music Therapy and the Cases of Orpheus, Empedocles and David. W: Music in Antiquity. The Near East and the Mediterranean, red. Joan Goodnick Westenholz, Yossi Maurey, Edwin Seroussi, 300-314. Berlin-Boston: de Gruyter.

Pseudo-Plutarch. 1992. O muzyce. Wrocław-Warszawa-Kraków: Ossolineum.

Radke, Barbara. 2021. Harfa, ryby i góralek. O jeziorze słów kilka. Galilea 13, 5-7.

Ranft, Patricia. 2014. Ruminations on Hildegard of Bingen (1098-1179) and Autism. Journal of Medical Biography, 22(2), 107-115.DOI: https://doi.org/10.1177/0967772013479283

Ratzinger, Joseph. 2012. Teologia liturgii. Sakramentalne podstawy życia chrześcijańskiego. Lublin: KUL.

Ravasi, Gianfranco. 2006. Piękno Biblii. Kraków: Wydawnictwo Salwator.

Rebić, Adalbert. 2001. Muzyka w Starym Testamencie. Communio 21(2), 11-19.

Romaní, Jorge. 2017. Causes and Cures of Skin Diseases in the Work of Hildegard of Bingen. Actas Dermosifiliogr. 108(6), 538-543. DOI: 10.1016/j.ad.2016.09.002

Rosińska, Klaudia. 2016. Król Saul jako przykład osoby chorej psychicznie w Starym Testamencie. Studia Koszalińsko-Kołobrzeskie, 23, 121-133. DOI: 10.18276/skk.2016.23-07

Rybowska, Joanna. 2020. Magia i religia w świecie starożytnych Greków (zarys problematyki). Collectanea Philologica 23, 23-51. DOI: https://doi.org/10.18778/1733-0319.23.03

Sachs, Curt. 1988. Muzyka w świecie starożytnym. Kraków: PWM.

Stamou, Lelouda. 2002. Plato and Aristotle On Music and Music Education: Lessons From Ancient Greece. International Journal of Music Education 39(1), 3-16. DOI: https://doi. org/10.1177/025576140203900102

Szczeklik, Andrzej. 2003. Katharsis. O uzdrowicielskiej mocy natury i sztuki, Kraków: Znak.

Szwed, Elżbieta. 2005. Zarys historii muzykoterapii. Prace Naukowe Akademii im. Jana Dlugosza $w$ Częstochowie, 1, 177-182.

Szymik, Stefan. 2014. Trishagion. Bóg po trzykroć Święty. Ethos 27(1), 21-34 . DOI 10.12887/272014-1-105-04

Tatarkiewicz, Władysław. 2009. Historia estetyki, t. 1, Warszawa: PWN.

Thaut, Michael. 2015. Music as Therapy in Early History. W: Music, Neurology, and Neuroscience: Evolution, the Musical Brain, Medical Conditions, and Therapies, red. Eckart Altenmüller, Stanley Finger, François Boller, 143-158. Amsterdam: Elsevier.

Tyrała, Robert. 2019. Znaczenie muzyki kościelnej w historii Kościoła. Perspektywy Kultury 1(24), 71-103. DOI: $10.35765 / \mathrm{pk} .2019 .2401 .07$

Waloszek, Joachim. 1995. Biblijne podstawy muzyki sakralnej (cz. 1). Liturgia Sacra 1(1-2), 113-122.

Walton, John i Mark Chavalas i Victor Matthews. 2005. Komentarz historyczno-kulturowy do Biblii Hebrajskiej. Warszawa: Vocatio. 
West, Martin. 2003. Muzyka starożytnej Grecji, Kraków: Homini.

West, Martin. 2016. Music Therapy in Antiquity. W: Music as Medicine: The History of Music Therapy since Antiquity, red. Peregrine Horden, 51-68. Abingdon: Routledge.

Wieczorek, Bartosz. 2013. Człowiek jako opus Dei i jego powrót do Boga w myśli św. Hildegardy z Bingen. Studia Theologica Varsaviensia 2, 259-284.

Wieczorek, Bartosz. 2016. Wokół języka pism wizyjnych św. Hildegardy z Bingen. Studia Theologica Varsaviensia 1, 201-222.

Williams, Gillian, Magdel le Roux. 2011. King Saul's mysterious malady. HTS Teologiese Studies / Theological Studies 68(1), 1-6. DOI: 10.4102/hts.v68i1.906

Wiśniewski, Piotr. 2013. Duchowość chorału gregoriańskiego. Liturgia Sacra 19(1), 103-118.

Woerther, Frédérique. 2008. Music and the Education of the Soul in Plato and Aristotle: Homoeopathy and the Formation of Character. The Classical Quarterly 58, 89-103. DOI: https://doi. org/10.1017/S0009838808000074

Wu, Yue. 2019. The Development of Music Therapy in Mainland China. Music Therapy Perspectives 37(1), 84-92. DOI: https://doi.org/10.1093/mtp/mix023

Zarewicz, Daniel. 2009. O orfickim języku mitu. Humanistyka i Przyrodoznawstwo 15, 225-240.

Jacek Bramorski - ks. dr hab., prof. Akademii Muzycznej im. Stanisława Moniuszki w Gdańsku, kierownik Katedry Muzyki Kościelnej. Prowadzi badania w zakresie teologii moralnej, teologii kultury, teologii muzyki i estetyki. e-mail: j.bramorski@amuz.gda.pl 